\title{
Climatic constraints to crop production and fertilizer use
}

\author{
T.L. Lawson ${ }^{1} \&$ M.V.K. Sivakumar ${ }^{2}$ \\ ${ }_{1}$ Agroclimatologist, International Institute of Tropical Agriculture, Ibadan, Nigeria \\ ${ }^{2}$ Principal Agroclimatologist, ICRISAT Sahelian Center, Niamey, Niger
}

Key words: Sub-Saharan Africa, climate, rainfall, erodibility, mulch

\begin{abstract}
The alarming food deficits projected for sub-Saharan African from recent production figures make it mandatory that no effort be spared in reversing the trend of declining yields. Developing better understanding of such climate-related constraints as high intensity storms, inadequate rainfall or poor rainfall distribution, high temperatures and high evaporative demands, excessive rainfall and high erodibility of soils will result in measures that can overcome or mitigate these constraints.
\end{abstract}

\section{Introduction}

Much has been written in recent years on the alarming demographic situation in Africa and on the continuing decline in food production in the region both in relative and absolute terms $[10,9]$. Projected food deficits in sub-Saharan Africa alone are estimated to be 27 to 34 millions tons by 1990 [14]. Many factors are responsible for the adverse trend in food production, but the central role of weather and climate has been well recognized particularly following the catastrophic drought of the early 70's and the recurring episodes that followed-being widespread as they were.

For example, about 30 million people continent-wide were reported to have been affected by drought in 1985 [46]. In terms of agricultural output, average yields of groundnut in Niger decreased from $850 \mathrm{~kg} / \mathrm{ha}$ in $1966-67$ to $440 \mathrm{~kg}$ / ha by 1981 again due mainly to drought and diseases [47]. Farther south in Nigeria, cassava, reputed for its resilience to adverse conditions and in particular its tolerance to drought, declined in yield from $10,592 \mathrm{~kg} / \mathrm{ha}$ in $1969-71$, to $9,167 \mathrm{~kg} / \mathrm{ha}$ in $1980-81$ [23].

The need for improved food production in West Africa has therefore never been more pressing, not only to avert hunger and starva- tion, but also to improve the lot of the countries of the sub-region. Agriculture is still the mainstay of the economies, and, for the majority of the people, the main source of livelihood. It is evident however that improvement in agricultural production can only take place in the context of a sound understanding and judicious use of the climatic potentialities in different regions of West Africa. The focus of this paper is therefore to review the climatic constraints to crop production and fertilizer use in the West African subregion.

\section{Climatic zones in West Africa}

It is difficult to review the climatic constraints in West Africa as a whole, since there is a distinct variation in the climatic characteristics as one moves from north to south. Initially, climatic zones in West Africa were delineated using mean annual rainfall as the criterion [2] because it shows a significant north-south gradient. Since 1949, several climatic zonation schemes have been proposed for West Africa, but the rainfall limits used for the zonation, in particular for the Sahelian zone, were different for different schemes $[25,41]$. Since potential evapotranspiration influences the proportion of rainfall avail- 
able for crop growth, Sivakumar [41] proposed a soil-climatic zonation scheme for West Africa using the growing period which is calculated from rainfall and potential evapotranspiration. In this scheme, the growing period of $60-100$ days was used for delineating the southern Sahelian zone, 100-150 days for the Sudanian zone, and 150-210 days for the Northern Guinea zone.

A parallel scheme based on the duration of the 'humid period' defined in terms of the number of months with rainfall equal to, or greater than, potential evapotranspiration was used by Lawson [28] to provide a unified zonation for the region as a whole (Fig. 1). The basic results superimposed on a vegetation map of the area derived from Keay [45] show the southern limit of the sahel running mostly along the 2-months isoline (Fig. 2); the Sudan Savanna reaching from the 2-months to the 4-months isoline, and the Northern Guinea Savanna covering mostly the area between the 4-months and 6-months humid period isolines, shifting north of the latter in central Nigeria. The 7-months humid period isoline essentially marks the southern limit of the Southern Guinea cum Derived Savanna zone; the true rainforest stretches more or less from the 7-month isoline to the coast except for a southward shift due to the Cameroon Mountains. There is, in effect, sufficient association between the regional climatic sub-units or zones shown in Figure 1 and the more commonly recognized vegetation/ecological zones for it to serve as a framework in examining the climatic constraints to crop production in the area.

\section{Climatic constraints}

The climatic conditions of West Africa as a resource base for crop production manifest a number of general and specific constraints. Consideration of these constraints can only be meaningfully made in terms of the relevant (climatic) variables affecting the morpho-physiological behaviour of the plants and/or the pertinent cultural practices. Furthermore, because of the presence of distinct climatic zones, it is important to recognize that these constraints may not necessarily be similar for the region as a whole. For example, lack of adequate rainfall and high evaporative demand constitute major constraints in the southern Sahelian Zone while water logging caused by heavy rains and poor drainage are major problems on the heavy soils in some areas of the Northern Guinea Savanna Zone and perhumid area of the rainforest zone. For this reason reference will be made to specific climatic zone in the discussion of these constraints.

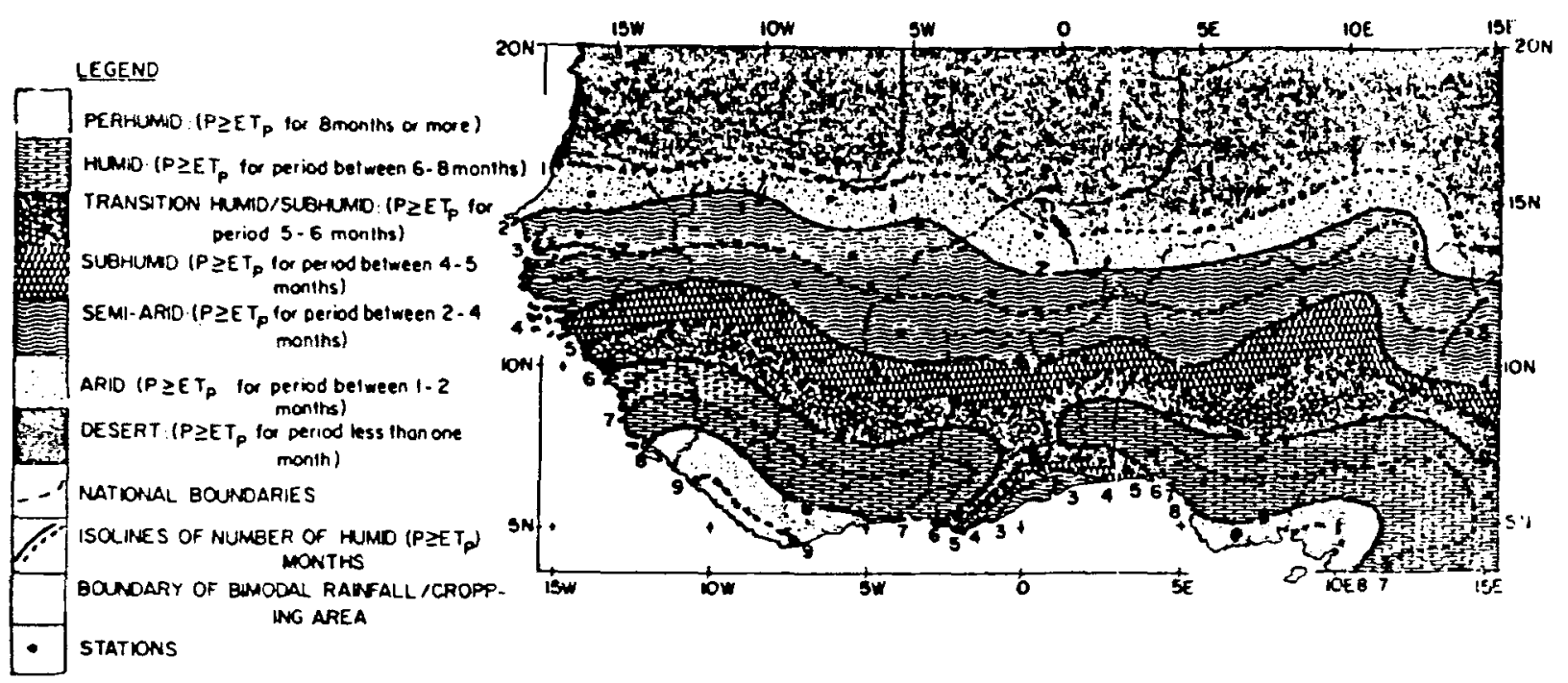

Fig. 1. Generalized agroclimatic map of West Africa [source: 27]. 


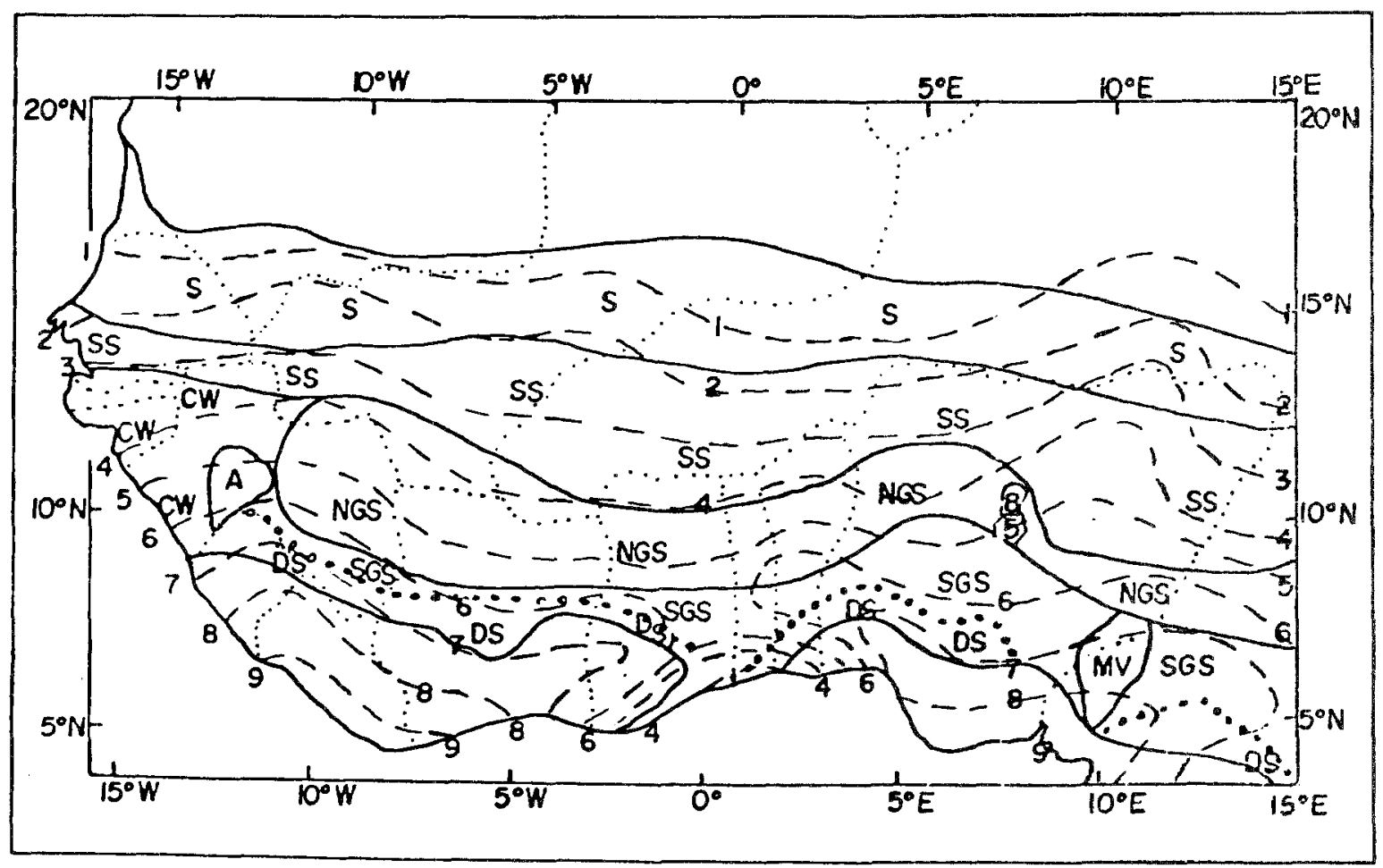

Fig. 2. West Africa: Composite map of vegetation zones and duration of humid period (No. of months with precipitation Pot evapotranspiration). Adopted from Steiner [45] and Lawson [27]. Legend $\sim \sim$ Number of months with rainfall $\geqslant$ Pot evapot; $\sim \sim$ Boundries of vegetation zones $S=$ Sahel, $S S=$ Sudan Savanna; $\cdots$ NGS $=$ Northern Guinea Savanna SGS $=$ Southern Guinea Savanna; 000 Northern Limit of Derived Savanna (DS).

\section{Rainfall: high variability in space and time}

Temporal and spatial variation in rainfall is a well marked characteristic of the West African region as a whole [27, Figs. $3 a-c]$. It is however in the drier areas that extreme conditions tend to prevail, both in terms of total variations and in terms of inadequacy.

As evidenced by Figure 3a, rainfall in the Southern Sahelian and Sudanian (the semi-arid) climatic zones are not only variable and undependable, but also generally low [41]. Because of this, significant deviations below the average frequently breach the minimum required for crop growth, setting off droughts. Often such deviations tend to persist for several years as the data for Ouagadougou show (Fig. 3a). Severe, extended droughts are thus a recurrent feature of the climate in these zones [35] but even so, the 1960-80 drought around Niamey, Niger was unique in its persistence. The large fluctuations in rainfall in the marginal areas in the Southern
Sahel and the Sudanian zones make agricultural systems in these areas very vulnerable. They also limit the potential for development [36].

In the Rain Forest Zone, negative departures in annual rainfall from the mean still leave actual totals that are in most cases sufficient to support reasonable crop growth and yield (Fig. $3 b$ after 32). It is the large positive departures that create conditions of excess moisture detrimental to crops. Except for transient incidences, such occurrences are not observed in the transitional, Derived Savanna zone which share the problem of inadequate rainfall with the drier zones.

\section{Rainfall: high intensity, runoff, soil erosion}

Another common feature of the rains in West Africa is their high intensities. In the drier zones to the north (southern Sahelian and Sudanian) most of the rains occur as short intense storms with peak intensities sometimes exceeding $100 \mathrm{~mm} / \mathrm{h},[5,19]$. At Bambey, in Senegal, ob- 

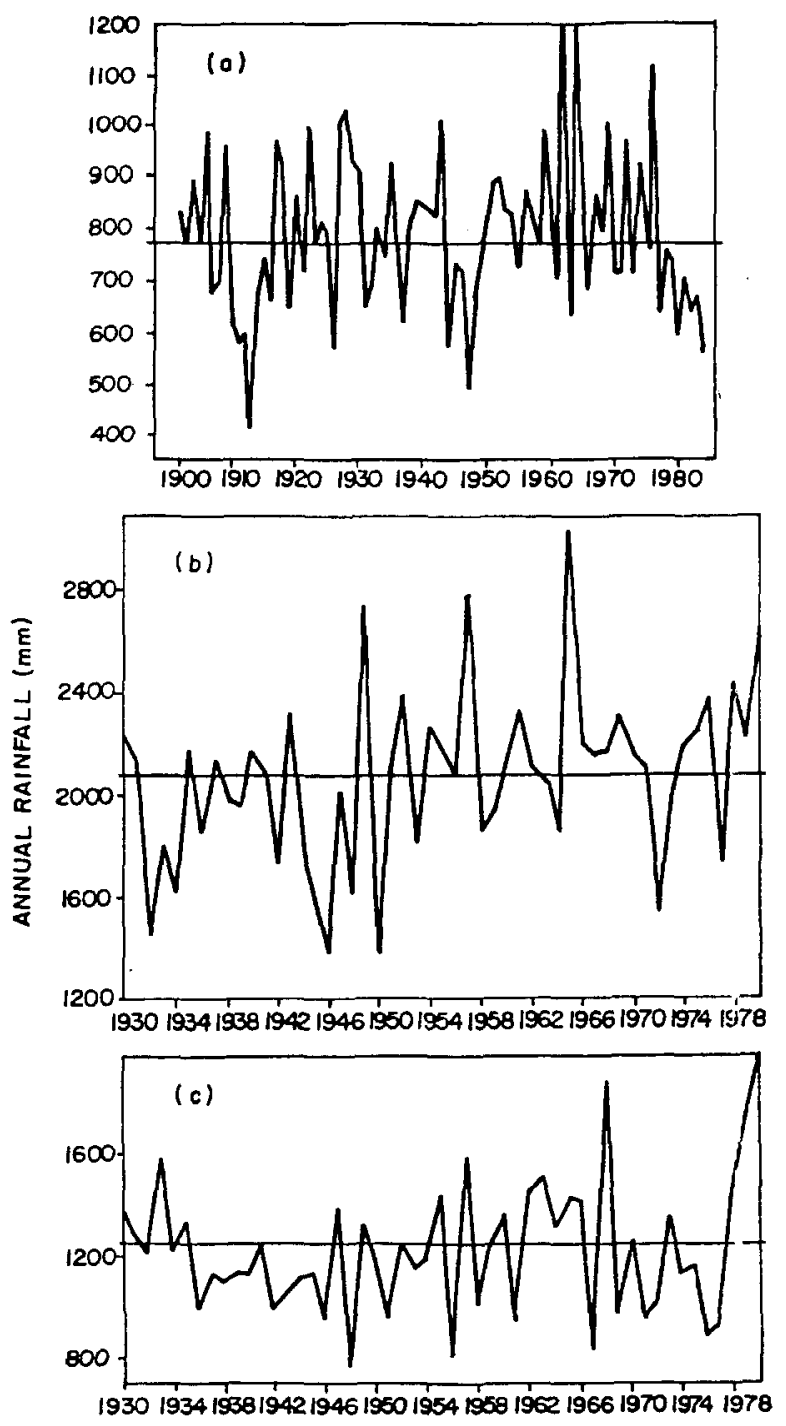

Fig. 3. Variation in annual rainfall at (a) Ougadougou, Burkina Faso, $\left(12^{\circ} 21^{\prime} \mathrm{N}, 1^{\circ} 31^{\prime} \mathrm{W}\right)$; (b) Benin City, Nigeria $\left(6^{\circ} 19^{\prime} \mathrm{N}, 5^{\circ} 36^{\prime} \mathrm{E}\right)$; and (c) Ibadan, Nigeria $\left(7^{\circ} 26^{\prime} \mathrm{N}, 3^{\circ} 54^{\prime} \mathrm{E}\right)$.

servations indicated that half of the rains fell with intensities greater than $27 \mathrm{~mm} / \mathrm{h}$ and a quarter with intensities greater than $52 \mathrm{~mm} / \mathrm{h}$ [4]. At Sefa, farther south, the corresponding values were 32 and $62 \mathrm{~mm} / \mathrm{h} \mathrm{[5].}$

Rainfall in the more humid areas of the Derived Savanna and the Rain Forest zones show a wider range of intensity distribution but the higher intensities are also mainly associated with thunderstorms $[27,24]$. Peak values in excess of $150 \mathrm{~mm} / \mathrm{h}$ sustained over $30 \mathrm{~min}$ have been observed both at Ibadan $\left(7^{\circ} 26^{\prime} \mathrm{N}, 3^{\circ} 54^{\prime} \mathrm{E}\right)$ and at
Onne (Port Harcourt, $4^{\circ} 51^{\prime} \mathrm{N}, 7^{\circ} 01 \mathrm{E}$ ) in Nigeria (Unpublished data, T.L. Lawson, IITA, Ibadan Nigeria). The higher amount and frequency of rains with such intensities in these wetter regions accentuate the associated problem of runoff and erosion. Soil loss values ranging from 11 to $33 \mathrm{t} / \mathrm{ha} / \mathrm{yr}$ on a $5 \%$ slope under maize-maize and cassave respectively have been reported [1].

On soils cropped to sorghum and cotton at Allokoto, Niger, in the southern Sahelian zone, Roose and Bertrand [40] reported soil loss of $8.6 \mathrm{t} / \mathrm{ha} / \mathrm{yr}$ while on bare soils at Sefa, Senegal, a much higher value of $21 \mathrm{t} / \mathrm{ha} / \mathrm{yr}$ under a higher mean rainfall of $1300 \mathrm{~mm}$ has been observed [4]. The general consequence of these soil losses is the rapid degradation and losses of productive capacity of the land over time. In marginal areas, this process may become irreversible and has led to instances of desertification in the Southern Sahelian zone.

\section{Solar radiation}

Solar radiation is more than adequate for primary photosynthetic functions of food and nonfood crops in the semiarid areas comprising the Southern Sahel, Sudanian and Northern Guinea Savanna zone [19]. In the more humid areas to the south, particularly in the transitional Derived Savanna zone and the Humid Rain Forest zone, considerable increase in amount and persistence of clouds cause reduction in insolation to suboptimal levels particularly during the rainy season, the period of crop growth $[19,27]$. This clearly constitutes a limitation on yield potential in these zones $[31,39]$.

\section{High temperatures}

Supra-optimal temperatures frequently occur in many areas of the region but with some degree of zonal differentiation evidently in relation to solar radiation and rainfall. In general the higher the radiation and the lower the rainfall, the higher the temperatures.

An analysis by Sivakumar [41] based on data from 64 stations in the Southern Sahelian and Sudanian climatic zones showed that during the crop growing season, maximum air temperatures vary from $28-42^{\circ} \mathrm{C}$. Mean maximum tempera- 
tures at the time of sowing (May-June) can exceed $40^{\circ} \mathrm{C}$. For the transitional zone (Derived Savanna), Lawson (27) also reported maximum air temperatures outside the $20-30^{\circ} \mathrm{C}$ range believed conducive for maximum photosynthesis in crops such as cowpea [33].

High soil temperatures also contribute to the adverse effect of air temperature on productivity in West Africa. On the sandy soils in Niger, surface temperatures (at $2 \mathrm{~mm}$ ) in June were reported to reach $45-50^{\circ} \mathrm{C}$ after a rain, leading to low stand survival [13] because of the sensitivity of the crop to high soil temperatures at the time of establishment. Seedling growth of soybean, cowpea, pigeon pea, in the Derived Savanna zone was also shown by Lal [20] to be adversely affected by soil temperatures exceeding $34^{\circ} \mathrm{C}$. The threshold value for maize was $30^{\circ} \mathrm{C}[20]$. These temperatures are frequently exceeded early in the cropping season [27]. Clearly therefore, high soil and air temperature must be considered significant constraints to crop production in West Africa as a whole and in the drier regions in particular.

\section{Wind speeds}

The surface wind regimes in the humid/ subhumid transition zone and in the rain forest areas are frequently marked by periods of calm or/and low wind speeds except just before and during rain showers and thunderstorms when gusts of up to $50 \mathrm{~km} / \mathrm{h}$ and above are observed. Peak wind speeds may reach up to $100 \mathrm{~km} / \mathrm{hr}$ as observed at ISC in the drier zone where mean wind speeds tend to be stronger. Kowal and Kassam [19] reported a short time maximum speed of up to $110 \mathrm{~km} / \mathrm{hr}$ at Samaru, in northern Nigeria. Incidence of these gusty winds during the crop growing season invariably results in mechanical damage to plants-mainly lodging [26]. The low wind speeds on the other hand apparently limit evapotranspiration and carbon dioxide exchange.

Moderate wind speed and limited moisture content of the air during the dry season and early in the cropping season considerably increase the evaporative demand and moisture stress on crops. Large quantities of fine sand and dust

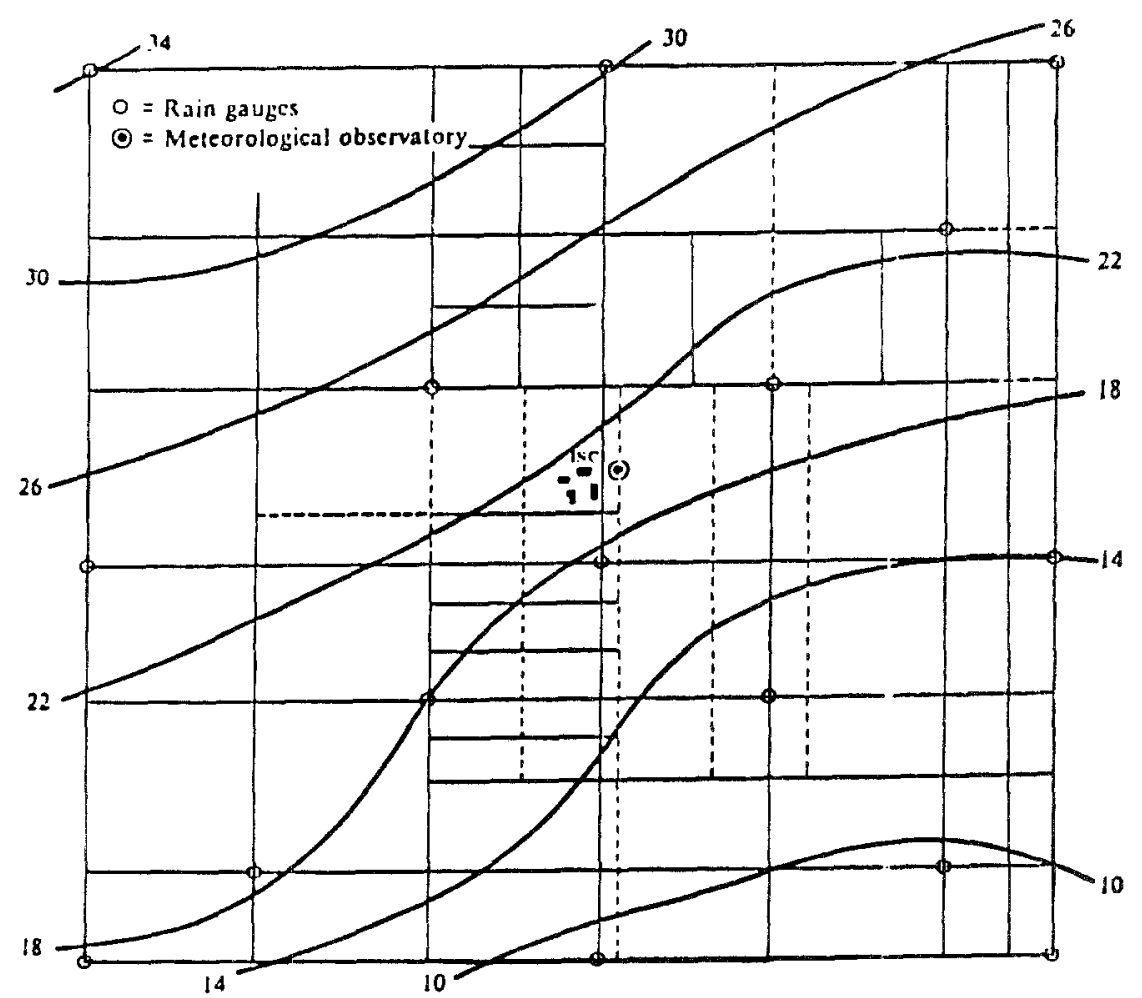

Fig. 4. Spatial variability of rainfall shown as Isohyets measured on a $400 \mathrm{~m}$ grid over 500 ha, ISC, Sadore, Niger, 22 July 1986. 


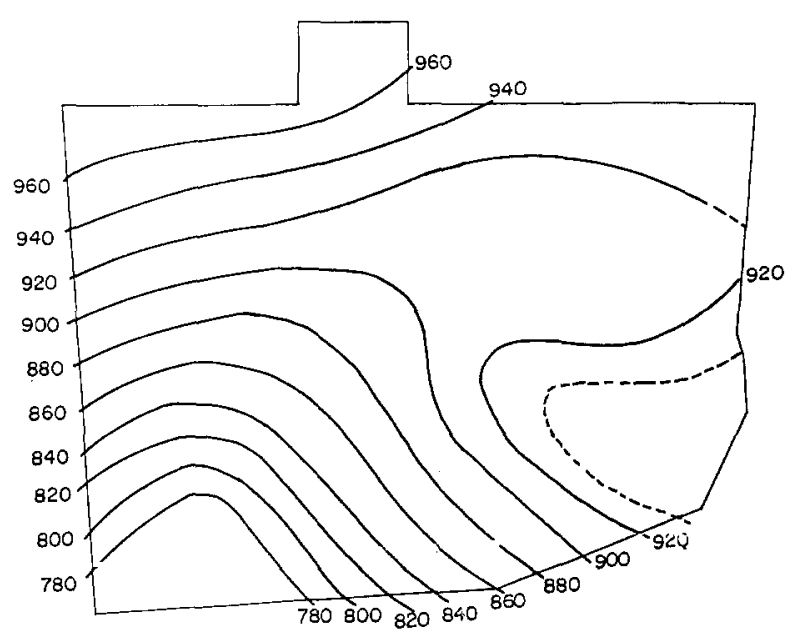

Fig. 5. Areal distribution of annual rainfall, IITA, 1977 (mm).

picked up from the bare soil surfaces in the Sahelian and Sudanian zones get washed by rain onto young seedlings, and virtually form a heating surface in contact with plants. Temperatures of these sand layers may reach lethal levels (up to $50^{\circ} \mathrm{C}$ ), damaging seedlings and thus contributing to problems of crop establishment.

\section{Potential evapotranspiration}

From the foregoing discussions it is evident that the radiation, temperature, wind and relative humidity conditions in the Southern Sahel and Sudanian zone are highly conducive to high evaporative demand and crop water requirements. Potential evapotranspiration rates are therefore generally high, resulting in annual totals in excess of rainfall. Kowal and Kassam [19] computed that north of latitude $8^{\circ} 19 \mathrm{~N}$, the annual deficit between rainfall and potential evapotranspiration, PE, increases by $200 \mathrm{~mm}$ per degree of latitude.

Seasonally favorable water balance makes cropping possible as shown in Figure 6. For Sadore and Dosso in the Southern Sahelian zone, rainfall exceeds $\mathrm{PE}$ demand for only a short time during the growing season. For Bengou located in the Sudanian zone, rainfall satisfies PE demand for over 8 decades. To the far south as observed earlier, this period is over 8 months in duration (Fig. 1).

\section{Erratic growing season lengths}

Since the PE demand in the Sahelian zone is consistently high and rainfall is erratic, the length of the growing season, defined by a favorable balance between the water supply and demand, varies essentially according to the variability of rainfall [26].

Lengths of the growing season computed from a 65-year rainfall record for Leo, Burkina Faso, is shown in Figure 7. The average length of the growing season is 166 days. Frequent negative rainfall departures from the average since 1973 resulted in growing season of below average durations. In poor rainfall years when the length of growing seasons is too short, crop failures could occur due to mismatch between the water availability and crop phenology. Similar situations may occur in other zones. In Ibadan in the Derived Savanna for instance the start of the rain in April is crucial for the normal duration of the cropping season. Low rainfall in April thus frequently delays planting. As shown in Figure 8, such was almost consistently the case from $1980-$ 87 [32].

\section{Climatic-related problems of soil fertility and fertilizer use}

The implications of the climatic characteristics of West Africa to soil fertility-related problems and practices are both direct and indirect. The high rainfall regime of the humid areas with the associated high rate of leaching accounts for the poor chemical characteristics (low nutrient reserves, low organic matter content, low CEC, high acidity, Al toxicity) of the Oxisols and Ultisols that form the bulk of the soils of the Rain Forest zone [11]. These soils, although reasonably well structured with good porosity, low bulk density, and high infiltration rate under the native forest vegetation, undergo rapid physical degradation when cleared and exposed to high intensity rain and traffic [22]. The problem is accentuated where there is hardened plinthite within the profile of Oxisols. The resulting shallowness of rooting depth affects moisture availability and fertilizer use efficiency. 

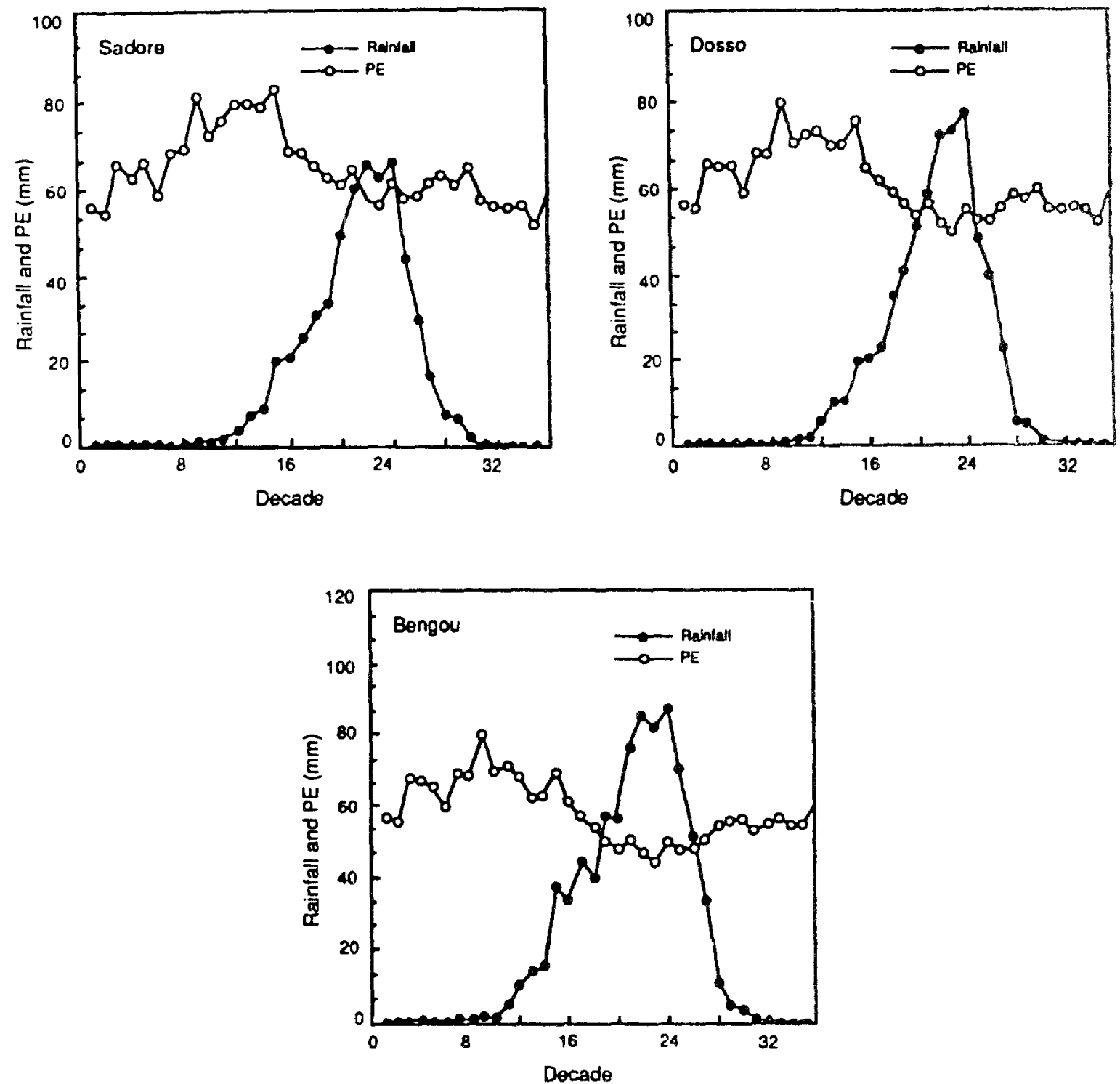

Fig. 6. Climatic water balance at three locations in West Africa. Sadore and Dosso are in the Southern Sahelian zone and Bengou in the Sudanian zone.

Alfisols which dominate the drier climatic zones (Southern Sahel, Sudanian, Northern Guinea Savanna) are also marked by high structural instability, low inherent fertility, low CEC and low organic matter content [37]. They are prone to compaction and surface crusting under the high intensity rain of this zone and are also rather erodible. Transient droughts in the Southern Sahel and Sudanian zones limit fertilizer efficiency while large water surplus during the humid period of the growing season in the Northern and Southern Guinea Savanna zones can result in pronounced leaching especially of nitrates $[16,19,38]$.

High soil temperatures in all areas but especially in the drier zone result in high rate of decomposition of organic matter and limit soil micro fauna and microbial activity $[15,23,3]$ all with important implications for fertilizer efficiency. 


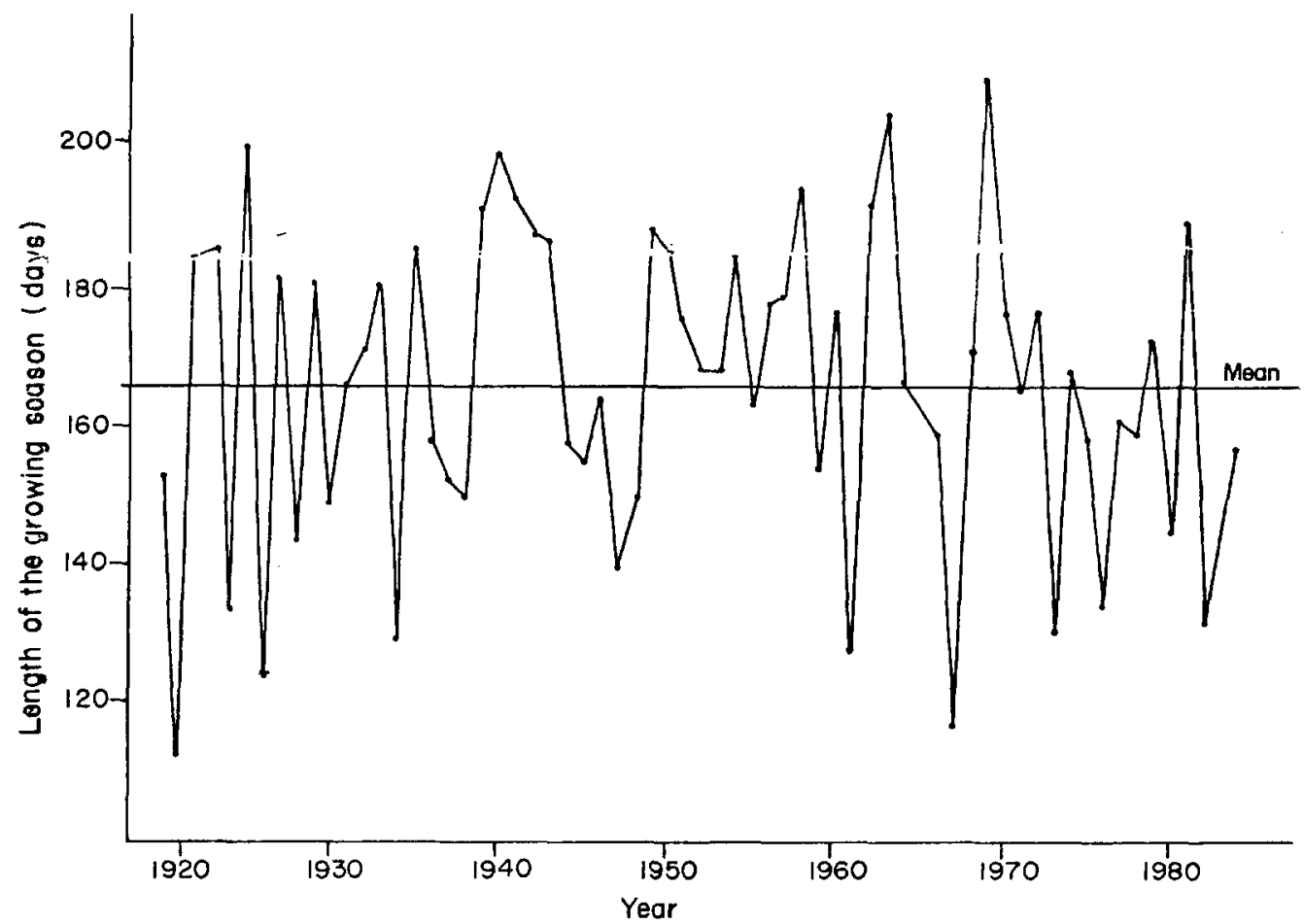

Fig. 7. Variation in the length of the growing season (days) at Leo, Burkina Faso (1920-1984).

Use of climatic analysis in developing crop production strategies in West Africa

From the preceding analysis of the climatic constraints for crop production in West Africa, it

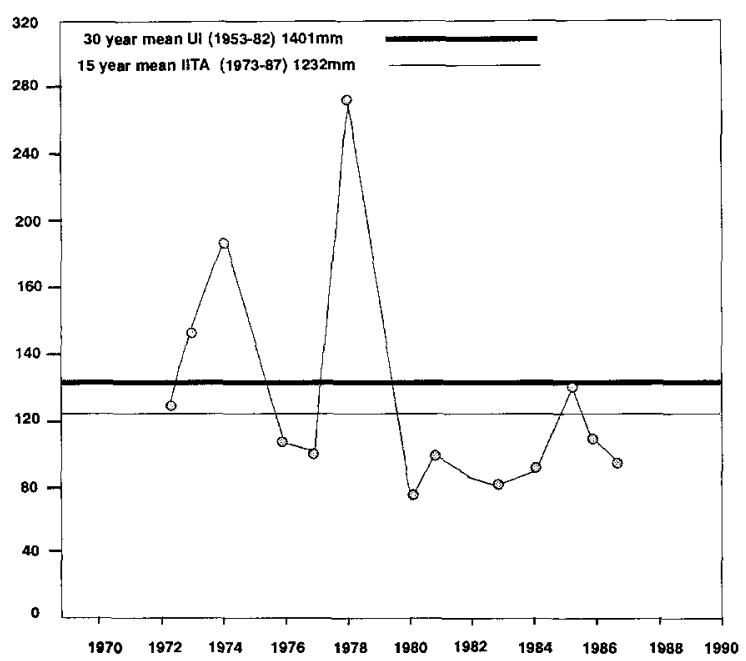

Fig. 8. IITA-Ibadan: Monthly rainfall for April. After Lawson $[27]$. should be apparent that a comprehensive analysis of the climatic data for the region is an essential prerequisite for developing stable cropping strategies, predicated on a better matching of the climatic attributes with the requirements of the crop species and varieties which constitute the genetic resource base. The time scale(s) of the analysis among other things therefore have to be consistent with morpho-physiological behaviour of the crops.

Useful information not readily seen in totals and means of given climatic variables could be derived from more detailed analysis of the appropriate long term historical data. Long term daily rainfall data for example could be used to compute probability of occurrence of different amounts of rain for different periods. Matching this with the crop water requirements, the cropping potential of the area or period can be assessed and cropping risks determined. This is of particular importance in the drier zones. Such analysis used in conjunction with current weather data could also be employed to facilitate tactical planning for intra-seasonal crop management decision. Application of $\mathrm{N}$-fertilizer for 
Table 1. Monthly and annual rainfall (mm) statistics at different locations in West Africa

\begin{tabular}{|c|c|c|c|c|c|c|c|c|c|c|c|c|c|c|c|c|c|c|c|c|c|c|c|c|c|}
\hline \multirow[b]{2}{*}{ Station } & \multirow[b]{2}{*}{ Eco-zone } & \multicolumn{3}{|c|}{ APRIL } & \multicolumn{3}{|l|}{ MAY } & \multicolumn{3}{|l|}{ JUNE } & \multicolumn{3}{|l|}{ JULY } & \multicolumn{3}{|l|}{ AUG. } & \multicolumn{3}{|l|}{ SEPT. } & \multicolumn{3}{|l|}{ OCT. } & \multicolumn{3}{|c|}{ ANNUAL } \\
\hline & & Mean & $S d^{b}$ & $\mathrm{Cv}^{\mathrm{c}}$ & Mean & $\mathrm{Sd}$ & $\mathrm{Cv}$ & Mean & $\mathrm{Sd}$ & $\mathrm{Cv}$ & Mean & $\mathrm{Sd}$ & $\mathrm{Cv}$ & Mean & $\mathrm{Sd}$ & $\mathrm{CV}$ & Mean & $\mathrm{Sd}$ & $\mathrm{Cv}$ & Mean & $S d$ & $\mathrm{Cr}$ & Mean & $\mathrm{Sd}$ & $\mathrm{Cv}$ \\
\hline $\begin{array}{l}\text { Niamey } \\
\left(13^{\circ} 29^{\prime} \mathrm{N}, 2^{\circ} 11\right)\end{array}$ & $\begin{array}{l}\text { Southern } \\
\text { Sahelian }\end{array}$ & - & - & - & 35 & 33 & 93 & 76 & 39 & 52 & 143 & 53 & 37 & 193 & 76 & 40 & 90 & 46 & 51 & 16 & 24 & 155 & 563 & 138 & 25 \\
\hline $\begin{array}{l}\text { Quagadougou } \\
\left(12^{\circ} 31^{\prime} \mathrm{N}, 1^{\circ} 31 \mathrm{~W}\right)\end{array}$ & Sudan $S^{a}$ & 20 & 23 & 112 & 73 & 49 & 67 & 115 & 48 & 42 & 188 & 51 & 27 & 262 & 89 & 34 & 150 & 54 & 36 & 36 & 33 & 90 & 855 & 140 & 16 \\
\hline $\begin{array}{l}\text { Minna } \\
\left(9^{\circ} 37^{\prime} \mathrm{N}, 6^{\circ} 32 \mathrm{E}\right)\end{array}$ & $\begin{array}{l}\text { Southern } \\
\text { Guinea S. }\end{array}$ & 56 & 41 & 73 & 49 & 57 & 43 & 173 & 72 & 41 & 219 & 93 & 42 & 258 & 99 & 38 & 269 & 96 & 36 & 134 & 66 & 49 & 1277 & 202 & 16 \\
\hline $\begin{array}{l}\text { Ibadan } \\
\left(7^{\circ} 26^{\prime} 3^{\circ} 54^{\prime} \mathrm{E}\right)\end{array}$ & Derived S. & 132 & 56 & 39 & 151 & 46 & 31 & 178 & 54 & 31 & 153 & 86 & 56 & 107 & 111 & 103 & 177 & 74 & 42 & 167 & 66 & 39 & 1235 & 263 & 21 \\
\hline $\begin{array}{l}\text { Benin City } \\
\left(6^{\circ} 19^{\prime} \mathrm{N}, 5^{\circ} 36^{\prime} \mathrm{E}\right)\end{array}$ & Rainforest & 172 & 67 & 39 & 194 & 57 & 29 & 285 & 80 & 28 & 349 & 163 & 47 & 242 & 141 & 58 & 335 & 99 & 30 & 235 & 95 & 44 & 2058 & 342 & 17 \\
\hline
\end{tabular}

instance may be deferred if there is strong likelihood of a heavy downpour or of drought.

In a more recent combination of long term climatic data and real time weather data analysis, Sivakumar [42] noted a highly significant relationship between the date of onset of rains and the length of the growing season across the Southern Sahelian and Sudanian zones. Using this as a prognostic tool, he computed the duration of the growing season for Ouagadougou, Burkina Faso, based on the early onset of the rain relative to the computed mean date of onset (Table 2).

The average date of beginning of rains at Ouagadougou is computed as 23 May, and the average length of the growing season is 117 days. However if the onset of rains occurs 20 days early ie., by 3 May, there is a $57 \%$ probability that the growing season will exceed 135 days. On the other hand, if the rain are delayed till 12 June, there is only a $7 \%$ probability that the growing season will exceed 115 days.

Table 2. Probabilities of growing season length exceeding specified durations for variable onset of rains for Ougadougou, Burkina Faso

\begin{tabular}{lcccr}
\hline $\begin{array}{l}\text { Date of } \\
\text { onset of } \\
\text { rains }\end{array}$ & \multicolumn{4}{c}{ Length of growing season (days) exceeding } \\
\cline { 2 - 5 } & 95 & 115 & 135 & 150 \\
\hline 3 May & 100 & 97 & 57 & 14 \\
13 May & 100 & 85 & 25 & 3 \\
23 May & 97 & 57 & 7 & 0 \\
2 June & 84 & 25 & 1 & 0 \\
12 June & 57 & 7 & 0 & 0 \\
\hline
\end{tabular}

The above analysis suggests that management tactics in the Southern Sahelian and Sudanian zones can be altered depending upon the onset of rains. In a field test of this methodology at Sadore, Niger (Southern Sahelian zone), it was shown that during years with early onset of rains, it is possible to grow a second crop of cowpea for fodder after the first crop of millet [43]. On the other hand, when precipitation is delayed 10 days beyond the calculated average date of onset of rains, short duration cultivars that will mature early in the remaining growing season are recommended. In addition, in terms of disaster planning, delayed rains signal the need for timely action since traditional and improved cultivars of median season length are likely to give poor yields.

Short-period rainfall probability analysis can also be used in the determination of agroclimatic analogues. Using this approach Sivakumar [41] showed that although Ouagadougou, Burkina Faso, and Kaolack, Senegal have a similar mean annual rainfall of $800 \mathrm{~mm}$, the two locations differed in rainfall dependability.

As a corollary to the short-period rainfall probability analysis, the probability of incidence of drought spells of different durations can be determined as guide in the selection of varieties and where moisture conditions permit, to shift time of sowing to avoid drought occurrence at the most sensitive phase of growth $[32,44]$. Cultural practices such as mulching can also be used to improve soil moisture storage and mitigate the effect of drought induced by rainfall irregularity [32]. 
The real time rainfall data collected through the large network of rain gauges that exist in West Africa have not been adequately exploited in estimating available soil moisture for crop growth. The systematic collection of evapotranspiration data for different crops in the region would be very helpful in developing suitable models for soil moisture prediction. For the Derived Savanna, the maximum evapotranspiration for a number of crops including rice, maize, cowpea and soyabean has been determined by Lawson and his collaborators [29, 30].

Commendable work has also been carried out by Dancette in Senegal $[6,7,8]$ on crop water requirements which were given as $413 \mathrm{~mm}$ for millet, 386 for groundnut, and 336 for cowpea. Using the water balance approach, Dancette [7] estimated the maximum cycle lengths for millet that will result in crop water needs being satisfied in 8 out of 10 years, and the probability that the water requirements of a 75 -day millet variety will be satisfied to at least the $80 \%$ level.

A subject of major concern in the agricultural systems of the Southern Sahelian and Sudanian climatic zones is the low plant population used by the farmers. This practice, which may have evolved over time as a survival mechanism, leads to considerable losses of the soil water through soil evaporation. Research on the physical processes of soil evaporation and transpiration carried out at the ICRISAT Sahelian Center in cooperation with the Institute of Hydrology, UK suggests that evaporation losses through the soil alone could exceed $40 \%$, immediately following rain. Hence suitable agronomic techniques need to be developed to minimize the losses and maximize the water use efficiency. Recent research by IFDC and the University of Hohenheim at ISC on soil mulches showed that considerable increases in water use efficiency and crop yields can be achieved by the use of soil mulches.

Surface mulching plays an unparalleled role in protecting the soil surface, in reducing runoff and soil erosion and thus prevent or slow down the deterioration of the soil [23]. The use of organic mulches such as crop residue or prunings from woody shrubs associated with crops in the field in an alley cropping system systematically adds organic matter to the soil. Since organic matter plays such a crucial role particularly in maintaining the productivity of the highly leached tropical soil, the system has proven to be an effective way of sustaining the productive capacity of the soil. It has also been shown to contribute significantly to fertilizer efficiency and improvement in crop yield $[17,23]$.

Efficiency of $\mathrm{N}$-fertilizer can be improved by appropriate decrease of rates of application under low solar radiation conditions. Studies in Ibadan by Nguu et al. [34] have shown that rice responded to rates of nitrogen application up to $120 \mathrm{~kg}-\mathrm{N} / \mathrm{ha}$ in the first season (February-June) under a higher insolation regime [26], but only up to a rate of $60 \mathrm{~kg}-\mathrm{N} / \mathrm{ha}$ in the second season (July-November) with less sunshine. Split application of nitrogen under the particularly high rainfall conditions of the Rain Forest zone has also proven effective in improving recovery by crop uptake.

\section{Summary and conclusions}

The alarming food deficits projected from recent production figures make it mandatory that no effort be spared in reversing the trend. From the point of view of the climatic resource base, analyses reveal important constraints likely to negate or lessen the effectiveness of the production system, given the strong dependence of crops on climate. Developing a better understanding of such constraints as high intensity erosive storms; inadequate rainfall and high evaporative demand in the drier areas to the north of the region, excessive rainfall and poor insolation in the humid/perhumid areas to the south, erratic lengths of the growing season, poorly structured and erodible soils low in nutrient content and moisture holding capacity, supra-optimal temperatures especially in the drier zones and occasionally destructive wind speeds will provide many options to overcome them or mitigate their impact on crop production. The development and application of management systems incorporating, among other things, accurate prediction of the start of the rains and incidence of drought spells, improvement in infiltration rates and soil moisture storage, and modification on soil temperature 
through the use of organic mulches, efficient use of fertilizer - all of these in cognizance of relevant crop attributes - can impact positively on efforts to increase food production in the subregion.

\section{References}

1. Aina PO, Lal R and Taylor GS (1977) Soil management in relation to soil erosion in the rainforest of western Nigeria. Pages $75-82$ in SCS Soil Erosion: Prediction and Control. Special Publication 211 USA

2. Auberville A (1949) Climats, fôrest et désertification de l'Afrique tropicale Soc Edit Geog Marit et Col Paris, $351 \mathrm{pp}$

3. Ayanaba A and Lawson TL (1977) Diurnal changes in acetylene reduction in field-grow cowpea and soybeans. Soil Biol Biochem 9: 125-129

4. Charreau C and Nicou R (1971) L'amélioration du profil cultural dans les sols sableux et sablo argileux de la zone tropicale sèche Ouest Africaine et ses incidences agronomiques. L'Agron Top 2 (2): 209-225; (5): 565631; (9): 903-978, 1183-1247

5. Chareau C (1974) Soils of tropical dry and dry wet climatic areas and use and management. A series of lectures, Cornell University, Ithaca, New York, USA

6. Dancette C (1974) Les besoins en eau des plantes de grande culture au Sénégal. In: Isotope and radiation techniques in soil physics and irrigation studies, 1973. pp 351-371 International Atomic Energy Agency Vienna, Austria

7. Dancette C (1976) Cartes d'adaptation à la saison des pluies des mils à cycle court dans la moité nord du Sénégal. In: Efficiency of water and fertilizer use in semi-arid regions. Vienna, Austria: FAO/IAEA Technical Document 192

8. Dancette C (1977) Agroclimatologie appliqué à l'économie de l'eau en zone soudano-Sahélienne. Bambey, Sénégal: ISRA

9. Davidson RK (1986) Population growth and agriculture in the IITA primary focus countries. A paper prepared for the IITA Program Strategy Planning Review. International Institute of Tropical Agriculture, Ibadan, Nigeria

10. FAO (Food Agricultural Organization of the United Nations) (1984) The state of food and agriculture, 1983. Food and Agricultural Organization of the United Nations, Rome

11. Greenland DJ (1981) Soils and crop production in the lowland humid tropics. Pages 1-9 In: Greenland DJ (ed) Characterization of soils in relation to their classification and management for crop production, Clarendon Press, Oxford

12. Harrison Church RJ (1980) West Africa 8th Edition Longman, London
13. ICRISAT (International Crop Research Institute for the Semi-Arid Tropics) (1985) Annual Report 1984 Patancheru, AP. 5023é' India; ICRISAT

14. IFPRI (1977) Food needs of developing countries: projections and consumption to 1990. Research report No. 3. International Food Policy Research Institute, Washington DC, USA

15. Jenkinson DS and Ayanaba A (1977) Decomposition of carbon-14 labeled plant material under tropical conditions Soil Sci Soc Am J 41 (5): 912-915

16. Jones MJ (1973) Time of Application of Nitrogen Fertilizer to Maize at Samaru, Nigeria. Experimental Agriculture 9: $113-120$

17. Kang BT, Wilson GF and Lawson TL (1984) Alley Cropping: A stable alternative to shifting cultivation. IITA, Ibadan, Nigeria

18. Keay RWJ (1958) Vegetation map of Africa south of the Tropic of Cancer. Oxford University Press, London

19. Kowal JM and Kassam AH (1978) Agricultural ecology of savanna: A study of West Africa. Clarendon Press, Oxford

20. Lal R (1974) Effects of constant and fluctuating soil temperature on growth, development and nutrient uptake by maize seedlings. PI Soil 40: 586-606

21. Lal R (1981) Deforestion of tropical rainforest and hydrological problems. Pages 131-140 In: Lal R and Russell EW (eds) Tropical Hydrology. John Wiley \& Sons, Chichester $482 \mathrm{p}$

22. Lal R (1981) Management of the soils for continuous production: controlling erosion and maintaining physical conditions. Pages 188-201 In: Greenland DJ (ed) Characterization of soils in relation to their classification and management for crop production. Clarendon Press, Oxford

23. Lal R (1987) Tropical Ecology and Physical Edaphology. John Wiley \& Sons, Chichester

24. Lal R, Lawson TL and Anastase AH (1980) Erosivity of tropical rains. Pages 143-151 In: DeBoodt $M$ and Gabriels D (eds) Assessment of Erosion. John Wiley \& Sons, Chichester

25. Lawson TL and Juo ASR (1979) Climate and soil conditions in the Sub-humid and Semi-arid Regions of West Africa with special reference to maize production. A paper presented at the first SAFGRAD Maize Production Workshop, Ouagadougou, Upper Volta, Feb. 20-23, 1979

26. Lawson TL, Oguntoyinbo JS and Ojo O (1979) Agriclimatic conditions of West Africa. A paper presented at the IITA Annual Research Conference on Soil and Climatic Resources and Constraints in Relation to Food Crop Production in West Africa. Oct. 15-19, 1979. IITA, Ibadan

27. Lawson TL (1980) Agroclimatic constraints to dry land rice production in West Africa. Pages 37-45 In: World Meteorological Organization and the International Rice Research Institute. Proceedings of a Symposium in the Agrometeorology of the Rice Crop. IRRI, Manila, Philippines

28. Lawson TL and Alluri K (1980) Maximum water requirement of upland rice variety OS 6 in the Humid/ 
Subhumid zone of West Africa. Pages 181-185 In: World Meteorological Organization and International Rice Research Institute. Proceedings of a Symposium on the Agrometeorology of the Rice Crop. IRRI, Manila, Philippines

29. Lawson TL (1981) Agroclimatic zones of West Africa. IITA Annual Report for 1980. International Institute of Tropical Agriculture, Ibadan, Nigeria

30. Lawson TL and Lal R (1982) Crop water requirements and water-use efficiency in the Humid/Sub-humid zone of West Africa. Proceedings Fourth Afro Asian Regional Conference of ICD, Lagos, Nigeria. 1: 505-513

31. Lawson TL and Alluri K (1986) Upland rice environments in Nigeria and the fitness of improved technologies. Pages 35-49 In: International Rice Research Institute, Progress in Upland Rice Research. IRRI, Manila, Philippines

32. Lawson TL (1988) Agrometeorology-The changing weather/climatic conditions and its implications for $\mathrm{Ag}$ riculture in the Tropics with Nigeria as a case study. A paper presented at the June Quarterly Luncheon Meeting of the Agricultural Trade Group of the Lagos Chamber of Commerce and Industry. June 29, 1988, Lagos Nigeria

33. Monteith IL (1977) Soil temperature and crop growth in the tropics. Pages 249-262 In: Lal R and Greenland DJ (ed) Soil Physical properties and crop production in the tropics. John Wiley \& Sons, Chichester

34. Nguu NV, Alam MS and Lawson TL (1987) Effect of Climate on Response to Nitrogen and insect infestation in irrigated rice. Pages 107-114 In: Rijks R and Mathys G (eds) Proceedings of the seminar on Agrometeorology and Crop protection in the Lowland Humid and Sub-Humid Tropics. Cotonou, Benin 7-11 July 1986. World Meteorological Organization, Geneva, Switzerland

35. Nicholson SE (1982) The Sahel: a climatic perspective. Club du Sahel, Paris, France: Organization for Economic Cooperation and Development (OECD)

36. Nicholson SE (1983) The climatology of Sub-Saharan Africa. pp 71-92 In: Environmental change in the West African Sahel. National Academy Press, Washington DC USA

37. Nnadi LA and Arora Y (1985) Effect of nitrogen sources and soil properties on crop yield in the savanna. Pages 223-233 In: Kang BT and van der Heide $J$ (eds) Nitrogen Management in Farming Systems in Humid and Subhumid Tropics. Institute for Soil Fertility (IB),
9750 RA, Haren, The Netherlands and International Institute of Tropical Agriculture (IITA), Ibadan, Nigeria, Haren (GR) The Netherland

38. Pieri C (1985) Management of Acid Tropical Soils in Africa. Pages 41-61 In: IBSRAM (International Board for Soil Resources and Management) Management of acid tropical soils for sustainable agriculture: proceedings of an IBSRAM inaugural workshop. Bangkok, Thailand

39. Posner JL (1978) Radiation Solaire et croissance et poductivité du riz pluvial (Oriza sativa) en Afrique de l'Ouest Agron Trop 33 (3): 275-290

40. Roose R and Bertrand RP (1971) Contribution á l'étude de la méthode des bandes d'arrêt pour lutter contre l'érosion hydrique en Afrique de l'Ouest. Résultats expérimentaux et observations sur le terrain. Agron Trop 26: 1270-1283

41. Sivakumar MVK (1986) Soil-climatic zonation for West African semi-arid tropics-implications for millet improvement. Presented at the Regional pearl Millet Workshop, Sep. 1986, Niamey, Niger

42. Sivakumar MVK (1987) Agroclimatic aspects of rainfed agriculture in the Sudano-Sahelian zone. Paper presented at the Workshop on 'Soil, Water and Crop/ Livestock Management Systems for Rainfed Agriculture in the Sudano-Sahelian Zone' 11-17 January 1987, Niamey, Niger

43. Sivakumar MVK (1988) Predicting rainy season potential from the onset of rains in the Sahelian and Sudanian climatic zones of West Africa. Agricultural and Forest Meteorology 42: 295-305

44. Sivakumar MVK (1989a) Drought spells and drought frequencies in West Africa. ICRISAT Sahelian Center, Niamey, Niger (Unpublished manuscript)

45. Sivakumar MVK (1989b) Exploiting rainy season potential from the onset of rain in the Southern Sahelian zone of West Africa. ICRISAT Sahelian Center, Niamey, Niger (Unpublished manuscript)

46. Steiner KG (1982) Intercropping in tropical small holder agriculture with special reference to West Africa, GTZ, Eschborn/TS.1

47. Timberlake L (1985) Africa in crisis. The causes, cures of environmental bankruptcy. Earthscan IIED, London

48. Toukoua D (1986) Welcoming address from Institut National de la Recherche Agronomique du Niger (INRAN). Page 11, In: Agrometeorology of groundnut. Proceedings of an International Symposium, 21-26 Aug 1985, ICRISAT Sahelian Center, Niamey, Niger 